\title{
Relationship between Fundamental Signals and Cash Flow Information on Stock Return after the Convergence of IFRS
}

\section{Ramly $^{1}$, Ismail Rasulong ${ }^{2}$, Buyung Romadhoni ${ }^{3}$, Diah Ayu Gustiningsih ${ }^{4}$, Alamsjah ${ }^{5}$ and St. Ramlah $^{6}$}

\author{
${ }^{1}$ Muhammadiyah University of Makassar, Indonesia \\ ${ }^{2}$ Muhammadiyah University of Makassar, Indonesia \\ ${ }^{3}$ Muhammadiyah University of Makassar, Indonesia \\ ${ }^{4}$ STIE Tri Darma Nusantara, Indonesia \\ ${ }^{5}$ Muhammadiyah University of Makassar, Indonesia \\ ${ }^{6}$ STIE Tri Darma Nusantara, Indonesia
}

\begin{abstract}
This study aims to find alternative information non-earnings (earnings) after IFRS convention in investing by testing (1) the relationship of fundamental information (account receivable signal, inventory signal, gross margin signal, sales, and administrative signal, effective tax signal, labor force and capital expenditure signal) on stock returns; and (2) Cash flows information (operating cash, investing cash and financing cash) on stock returns. This research was conducted on the Indonesia Stock Exchange (IDX) using secondary data. Sampling was carried out purposively and resulted in 175 observational data in 2012-2016. Data were analyzed using multiple linear analysis methods. The results showed (1) fundamental information such as account receivable, sales and administrative expenses and capital expenditure had a significant effect on stock returns, while fundamental signals such as inventory, gross margin, effective tax rate, labor force showed insignificant results; and (2) Cash flow information such as operating cash flows, investing cash and financing cash also provide insignificant results. Based on the results of these studies it can be concluded that fundamental information such as account receivable signal, sales, and administrative signal and capital expenditure signal can be used as alternative information in investing after IFRS convergence.

Keywords: Fundamental Information, Cash Flow Information, Stock Returns
\end{abstract}

\section{Introduction}

There is a standard revision that is effective in 2011/2012, as stated by Sukendar (2009) the convergence aims that was announced by IAI in 2012 is to revise the PSAK so that it is materially in accordance with IFRS version 1 January 2009, which is effective 2011/2012. Therefore, this study intends to reexamine the relationship of fundamental information and cash flow information to stock returns. This relationship implies investor reaction to financial statement information after IFRS convergence.

Fundamental information and cash flow information is alternative information because based on research Bernard and Thomas (1990) found that companies were not able to reflect stock prices in full so that alternative information was needed as an investment decision step. Information failure earnings (earnings) in reflecting stock prices is also strengthened in the study of Amir and Lev (1996), which found the fact that the weak association between earnings to stock returns. Previously, earnings became the foundation of investors in investing where it was based on Ball research and Brown (1968) and Beaver (1968), which provide the empirical result of the effect of earnings on stock returns. This failure implies that there are various types of non-profit (earnings) information in the financial statements that are more reacted by the market. Livnat and Zarowin (1990) research, introduces information on cash flow components, while Lev and Thiagarajan (1993), introduce fundamental signals as information on non-profits (earnings) that can be considered in making decisions used in investing. 
Fundamental information and cash flows information have been used separately for certain studies by several previous researchers, for example research on information fundamental signals was examined by $\mathrm{Ou}$ and Penman (1989), Lev and Thiagarajan (1993), Abarbanel and Busshe (1997, 1998), Sharma and Preeti (2009), Elleuch and Trabelsi (2009), Shen and Lin (2010) and Luch et al (2011), while in the study of information the components of cash flow are examined by Wilson (1986), Rayburn (1986), Bernad and Stober (1989), Bowen et al (1986) and Livnat and Zarowin (1990).

Some studies provide empirical evidence of the relationship of fundamental information to stock returns including Lev and Thiagarajan (1993), which examines the effects of fundamental information such as inventory signal, account receivable signal, capital expenditure signal, R\&D signal, gross margin signal, sales and administrative signal ( $\mathrm{S} \& \mathrm{~A}$ ), provision for doubtful receivable signal, effective tax signal, order backlog signal, labor force signal, LIFO earnings and audit qualification have a positive (negative) effect on stock returns. Elleuch and Trabelsi (2009), shows the results of fundamental signals such as inventory, account receivable, investment, gross margin, and labor force have a correlation to stock returns. Shen and Li (2010), in his research, showed significant results on inventory risk, gross margin, provision for doubtful receivables, sales and administrative expenses, labor forced results that were not significant on signal effective tax rates and expenditure R \& D. Luch et al (2011), obtained insignificant results in inventory signals, account receivable signals, R $\& \mathrm{D}$ expenditure, qualification audits, and effective tax rates.

Empirical evidence of the relationship of cash flow components to stock returns including Rayburn (1986), proves the relationship between cash flow of operations and accrual profit with stock returns. Bernard and Stober (1989), the separation of cash flow from operations and cash flows from funding can improve relationships with stock returns. Livnat and Zarowin (1990), prove that the cash flow component has a stronger relationship with stock returns than the relationship between total cash flows and stock returns.

The study of Barlev and Livnat (1989) shows that the cash flow ratio has a stronger relationship to stock prices than the balance sheet and profit and loss ratio, but in Kargin's research (2013), shows an increase in book value reaction (balance sheet representation) and earnings per share (representation profit and loss) on stock prices after the transition of GAAP standards to IFRS. Based on this description and the results above, this study aims to find non-profit (earnings) information alternatives after IFRS convergence by testing (1) the relationship of fundamental signals (representation of balance sheet statement and profit and loss statement) to stock returns and (2) information cash flow component to stock returns. The testing was carried out simultaneously so that it can be seen which of the two variables were more reacted by the market after the transfer of accounting standards towards IFRS.

\section{Research Methodology}

The location of research was conducted at the Indonesia Stock Exchange (Makassar Capital Market Information Center representative) using secondary data from 2012 to 2016. This study aimed to test the hypothesis. The type of relationship between variables studied is correlational relationships. The unit of analysis is the company level, namely manufacturing companies listed on the Indonesia Stock Exchange (IDX). The time horizon in this study is the time series. The variables in this study consist of dependent variables and independent variables. The dependent variable used is fundamental information consisting of inventory signal, account receivable signal, capital expenditure signal, gross margin signal, sales, and administrative signal, effective tax signal, labor force signal, and cash flow information consisting of operating cash, financing cash, and investing cash. Independent variables are stock returns.

The population of this research is all manufacturing companies listed on the Indonesia Stock Exchange (BEI) in 2012-2016. Sample selection was done by purposive sampling method. Companies that meet the requirements to be sampled in this study are as many as 35 companies. 
Data in this study were collected through searches on a computer on the Indonesia Stock Exchange (IDX) website and the Indonesia Capital Market Directory (ICMD). Secondary data consists of financial statements of companies that go public that have been audited by independent public accountants. The financial statement data is collected directly from the Capital Market Reference Center at the Indonesia Stock Exchange building (IDX) and comes from the Indonesia Capital Market Directory. Stock price movement data is obtained through www.yahoo.finance.com.

The hypothesis in this study was tested using multiple linear regression using SPSS17 software. The regression model in this study is shown in the following equation:

Return $=\alpha+\beta_{1} A R+\beta_{2} I N V+\beta_{3} G M+\beta_{4} S A+\beta_{5} E T+\beta_{6} L F+\beta_{7} C P+\beta_{8} O C F+\beta_{9} I C F+\beta_{10} F C F+\mu$ Information:

Stock return $=$ Stock return is proxied by cumulative abnormal return;

$\alpha=$ Constant;

$\beta \quad=$ Coefficient;

$\mathrm{AR}=$ Account receivable is measured by the percentage of changes in trade receivables deducted by the percentage of sales changes;

INV = Inventory is measured by the percentage of inventory changes reduced by the Percentage of sales changes;

$\mathrm{GM}=$ Gross margin measured by the percentage change in gross profit reduced by the percentage change in sales;

SA = Sales and administrative expenses are measured by the change of percentage in sales and administration are reduced by the percentage of sales changes;

ET = Effective tax rate is measured by the percentage of income before tax at current time (t) multiplied by the effective tax percentage

$\mathrm{LF}=$ Labor force is measured by sales at time $\mathrm{t}-1$ divided by the number of workers at time $\mathrm{t}-1$, then the results are reduced by the results of the division of sales at time $t$ divided by the number of workers. The subtraction results are then divided by sales of $t-1$. Then the results of the division are divided into the number of workers on $\mathrm{t}-1$;

$\mathrm{CP}=$ Capital expenditure is measured by the percentage change in the expenditure of the firm reduced by the percentage of manufacturing expenditure;

$\mathrm{OCF}=$ Operating cash is measured by the change of percentage in one year from the total cash flow from operating activities;

ICF = Investing cash measured by the change of percentage in one year from the total investment cash ;

FCF $=$ Financing cash is measured by the change of percentage in one year from the total funding cashes.

\section{Results and Discussion}

Hypothesis test results (Table 1) show that some fundamental signal variables negatively affect stock returns, while the information component of the current component has no effect on stock returns. Fundamental signals obtain significant results at alpha level of 5\% such as account receivable obtain a significance value of 0.007 and coefficient value of -0.224 , expensive sales and administrative get a significance value of 0.001 and coefficient value of -0.424 , capital expenditure obtains a significance value of 0.046 and coefficient value of 0.013 Meanwhile, information on cash flow components and other fundamental signals shows insignificant results such as operating cash flows, obtaining a significance of 0.899 with a coefficient value of 0.00 , investing cash flows obtain a significance value of 0.498 with a coefficient value of -0.004 , financing cash flows obtain a significance value of 0.671 with a coefficient value 0.001 , inventory obtained a significance value of 0.961 with a coefficient value of -0.006 , gross margin obtained a significance value of 0.709 and a coefficient value of 0.045 , the effective tax rate obtained a significance value of 0.515 with a coefficient value of 2.48 , labor force obtained a significance value 0.790 with a coefficient of -0.008 . 
Table 1. Hypothesis Test (Coefficients ${ }^{\mathrm{a}}$ )

\begin{tabular}{|c|c|c|c|c|c|c|}
\hline \multirow{2}{*}{\multicolumn{2}{|c|}{ Model }} & \multicolumn{2}{|c|}{$\begin{array}{l}\text { Unstandardized } \\
\text { Coefficients }\end{array}$} & \multirow{2}{*}{$\begin{array}{c}\text { Standardized } \\
\text { Coefficients } \\
\text { Beta }\end{array}$} & \multirow[b]{2}{*}{$\mathrm{t}$} & \multirow[b]{2}{*}{ Sig. } \\
\hline & & B & Std. Error & & & \\
\hline \multirow[t]{11}{*}{1} & (Constant) & .097 & .031 & & 3.153 & .002 \\
\hline & $\mathrm{AR}$ & -.224 & .082 & -.380 & -2.746 & .007 \\
\hline & INV & -.006 & .121 & -.034 & -.049 & .961 \\
\hline & GM & .045 & .122 & .292 & .373 & .709 \\
\hline & SAE & -.424 & .125 & -2.371 & -3.386 & .001 \\
\hline & ET & 2.48 & .000 & .129 & .652 & .515 \\
\hline & $\mathrm{LF}$ & -.008 & .030 & -.073 & -.267 & .790 \\
\hline & CAPEX & .013 & .006 & 1.795 & 2.014 & .046 \\
\hline & $\mathrm{OCF}$ & .000 & .005 & -.010 & -.127 & .899 \\
\hline & ICF & -.004 & .006 & -.051 & -.679 & .498 \\
\hline & FCF & -.001 & .003 & -.032 & -.425 & .671 \\
\hline
\end{tabular}

a. Dependent Variable: Return

This research shows that fundamental information and cash flow information has mixed results. Most fundamental information shows significant results such as account receivable, sales and administrative expenses, and capital expenditure while inventory, gross margins, effective tax rates, labor forces, operating cash, investing cash, financing cash get results that not significant. Some of the variables described in the hypothesis are in line with the theory, the fundamental signal variables that are interpreted and predicted by the analyst get significant results. This means that the content of information from fundamental information can be understood by investors which are then used in valuation. On the other hand, based on market efficiency theory, if the information disseminated is bad information, the stock price will drop (negative) and so good information on the company will make the stock price rise (Manurung, 2012). This result also shows that the fundamental signal was more reacted by investors than information on the cash flow component after the convergence of accounting standards became IFRS since 2012.

The effect of negative account receivable on stock returns shows that investors in the capital market understand that the company has difficulty in generating cash sales which then increases the risk of uncollectible receivables so that future earnings are expected to decline. The results of this research are in line with the study of Lev and Thiagarajan (1993); Abarbanel and Bushee (1997) and Shen and Li (2010).

Almost all sales and administrative expenses are large so that disproportionate increase in sales and administrative expenses against sales is interpreted as a managerial failure in the supervision of costs (Suryanigrum and Jogiyanto, 2000). stock return. The results of this research are in line with Lev and Thiagarajan (1993), Abarbanel and Bushee (1997) and Shen and Li (2010).

This research also shows the positive influence of capital expenditure on stock returns, in this case, Seng and Hancock (2012), argues that the level of capital expenditure by companies less than the industry can provide negative signals about future growth. This can be interpreted as industrial growth will be better than company growth which then becomes bad news for investors. The results of this research are in line with Lev and Thiagarajan (1993) and Abarbanel and Bushee (1997).

Inventory signal, gross margin signal, effective tax signal, and labor force signal are fundamental information variables that get insignificant results due to the level of analysis of the information content of these signals. According to Marfuah (2006), sophisticated investors (sophisticated 
investors) should be able to interpret and analyze information, to be able to distinguish the information of economic value and not of economic value. Non-significant results show investors are still not sophisticated in understanding signal information. This concept of investor sophistication can be explained in the development of an efficient market where information does not only emphasize the fully reflecting aspect but also the sophistication of investors (sophisticated investors) (Jogiyanto, 2008; 2012).

Operating cash, investing cash, and financing cash is information variables of cash flows that also have insignificant results due to the convergence of PSAK from GAAP to IFRS. IFRS places more emphasis on the fair value which reflects the present value. By more reflecting current information, accounting for fair valuation is more relevant in decision making (Subranyaman and Will, 2010). Changes from historical cost to fair value show an increase in investor confidence in the financial statement (balance sheet) and comprehensive income statement which in this study are proxied through fundamental signals while information on cash flow components is not used by investors in decision making.

\section{Conclusion}

Results of hypothesis testing show that most of the fundamental signals can be reacted by the market while the information on the cash flow component fails to be reacted by the market. Some theoretical explanations as described earlier fundamental signals are more reacted by the market due to a shift in accounting standards from GAAP to IFRS which then affects the reading of the content of each information. As for fundamental signals such as inventory, gross margins, effective tax rates, and labor forces in the perspective of information content theory explain that information content fails to be captured by investors, while the perspective of market efficiency theory explains the market not only reacts to available information but also highly dependent on the sophistication of investors (sophisticated investors) in understanding information. Based on this, researchers should expand the research population and extend the number of observations so that they can generalize the results of research, especially on the Indonesia Stock Exchange. The weak relationship between fundamental signals and information on cash flow components is expected to research afterward can use moderation variables in order to strengthen the relationship between fundamental signals and information on cash flow components. For investors, especially in the Indonesia Stock Exchange should not only consider earnings in invest but also consider fundamental signal information which in this study proved to provide significant results such as account receivable signals, sales and administration expenses, and capital expenditure.

\section{References}

Abarbanel.J; Busshee. (1997). Fundamental Analysis, Future Earnings, Stock prices. Journal of Accounting Research 35 (Spring): 1-24

Abarbanel.J; Busshee. (1998). Abnormal Return to A Fundamental Analysis Strategy. The Accounting Review. 73 January: 19-45

Amir, Eli; Lev, Baruch, (1996). Value-Relevance of non-financial information: The Wireless Communication industry. Journal of accounting and Economic. 22. 3-30

Ball, R.; Brown, P. (1968). An Empirical Evaluation of Accounting Income Numbers. Journal of Accounting Research (Autumn). pp. 159-177.

Barlev, Benzion; Livnat, Joshua.(1989). The Incremental Content Of Fund Statement Ratios. Journal Accounting, Auditing, and Finance, pp.155-192

Beaver, W. H. (1968). The Inforniation Content of Annual Earnings Announcements.Journal of Accounting Research 6: 67-92.

Bernard, Victor; Thomas, Jacob .(1990). Evidence that stock do not fully reflect the implications of current earning for future earning. Elsevier Sience publisher B.V. (North Holand). 
Bernard, V. L.; Stober, T. L.(1989). The Nature and Ammount of Information in Cash Flows and Accruals. The Accounting Review 64 (October): 624-652.

Bowen, Robert M.; David Burgsthler; Lane A. Daley. (1986). Evidence on The Relationships between Earnings and Variouss Measures of Cash Flows. The Accounting ReviewVol XI No. 4 (October): 213-225.

Elleuch, Jaouida; Trabelsi, Lotfi. (2009). Fundamental Analysis Strategy and the Prediction of Stock Returns.International Research Journal of Finance and Economics ISSN 1450-2887 Issue 30.

Jogiyanto H.M. (2008). Teori Portofolio dan Analisis Investasi. Edisi 7. BPFE. Yogyakarta

Jogiyanto H.M. (2012). Pasar Efisien secara Informasi, Operasional, dan Keputusan, Edisi 2. BPFE. Yogyakarta.

Kargin, Sibel. (2013). The Impact of IFRS on the Value Relevance of Accounting Information: Evidence from Turkish Firms. International Journal of Economics and Finance; Vol. 5, No. 4

Lev, Baruch; Tiagarajan, S.R. (1993). Fundamental Information Analysis. Journal Of Accounting Research Vol. 31 No. 2 Autumn.

Livnat, Joshua; Zarowin, Paul. (1990). The Incremental Content of Cash Flow. Journal of Accounting and Economic: 25-46.

Luch, Crish; Maheshwari, Suneel; Myring, Mark.(2011). An examination of future firm performance and fundamental analysis. Journal of Finance and Accountancy

Manurung, A.M. (2012). Teori Investasi: Konsep dan Empiris. STIEP Press. Jakarta

Marfuah.(2006). Pengaruh Kecanggihan Investor Terhadap Ketepatan Reaksi Pasar Dalam Merespon Pengumuman Dividen Meningkat.JAAI.Volume 10 NO. 2: 137-154

Ou.J.; Penman, S. (1989).Financial Statement Analysis And Prediction Of Stock Return. Journal Of Accounting And Economic. (11 November): 295-330.

Rayburn, Judy. (1986). The Association of Operating Cash Flowsand Accruals with Security Return.Journal of Accounting Research 24:112-138

Sharma, Meena; Preeti. (2009). Prediction Of Stock Returns For Growth Firm: A fundametal Analysis. The Journal of Business Perspective, Volume 13. No. 3

Seng, Dyna; Hancock, Jason. (2012). Fundamental Analysis and the Prediction Of Earnings. International Journal Of Busisness and Management.

Shen, Chung-Hua; Li Lin,Kun. (2010). The Impact of Corporate Governance on the Relationship Between Fundamental Information Analysis and Stock Returns Emerging Markets Finance \& Trade Vol. 46, No. 5, pp. 90-105

Sukendar, Heri. (2009). Konvergensi Standar Laporan Keuangan Ke Standar Pelaporan Keuangan Internasional. Journal The WINNERS, Vol. 10 No. 1, Maret 2009: 10-21

Suryaningrum, Anik; Jogiyanto, H.M. (2000). Abnormal Return dengan Strategi Analisis Fundamental. SOSIOHUMANIKA, 13(3) September 2000.

Subramanyam K.R; Wild, John. (2010). Financial Statement Analysis. Salemba Empat Edisi Ke 10. Jakarta

Wilson, G.P. (1986). The Relative Information Content of Accruals and Cash Flows: Combined Evidence at the Earnings Announcement and Annual Report Release Date. Journal of Accounting Research Vol. 24 


\section{Appendices}

\begin{tabular}{|l|r|r|r|}
\hline & \multicolumn{4}{|c|}{ Descriptive Statistics } \\
& Mean & \multicolumn{1}{c|}{$\begin{array}{c}\text { Std. } \\
\text { Deviation }\end{array}$} & \multicolumn{1}{c|}{$\mathrm{N}$} \\
\hline Return & .0614 & .39268 & 174 \\
AR & .0180 & .66646 & 174 \\
INV & .2215 & 2.26605 & 174 \\
GM & .1944 & 2.52017 & 174 \\
SAE & .2117 & 2.19612 & 174 \\
ET & - & $2.04509 \mathrm{E} 12$ & 174 \\
& $1.8463 \mathrm{E} 1$ & & \\
& 1 & & \\
LF & -.4004 & 3.64794 & 174 \\
CAPEX & 4.0766 & 54.35028 & 174 \\
OCF & .4873 & 5.95871 & 174 \\
ICF & .3153 & 4.76820 & 174 \\
FCF & -.8346 & 9.11327 & 174 \\
\hline
\end{tabular}

Model Summary

\begin{tabular}{|l|r|r|r|r|}
\hline Model & \multicolumn{1}{|c|}{$\mathrm{R}$} & R Square & $\begin{array}{c}\text { Adjusted R } \\
\text { Square }\end{array}$ & $\begin{array}{l}\text { Std. Error of } \\
\text { the Estimate }\end{array}$ \\
\hline 1 & $.345^{\mathrm{a}}$ & .119 & .065 & .37967 \\
\hline
\end{tabular}

a. Predictors: (Constant), FCF, ET, ICF, OCF, AR, LF, SAE, INV, GM, CAPEX 